\title{
Studies on Copper(I)cyanides
}

\author{
BO NORBERG and BERTIL JACOBSON \\ Biochemical Department, Karolinska Institutet, Stockholm, Sweden
}

$\mathrm{T}$ The biological antagonism between copper(II)ions and cyanide was discovered by Chistoni in $1925^{1}$. Later it has been demonstrated that cyanide inactivation of certain enzyme systems can be reversed by means of copper(II)ions (see e.g. Kubowitz ${ }^{2}$ ). Thereby one of the following reactions may take place:

$$
\begin{aligned}
& 2 \mathrm{Cu} \cdots+4 \mathrm{CN}^{\prime}=2 \mathrm{CuCN}+(\mathrm{CN})_{2} \\
& 4 \mathrm{Cu} \cdots+8 \mathrm{CN}^{\prime}=2 \mathrm{CuCN}, \mathrm{Cu}(\mathrm{CN})_{2}+(\mathrm{CN})_{2} \\
& 2 \mathrm{Cu} \cdots+6 \mathrm{CN}^{\prime}=2 \mathrm{Cu}(\mathrm{CN})_{2}^{\prime}+(\mathrm{CN})_{2} \\
& 2 \mathrm{Cu} \cdots+7 \mathrm{CN}^{\prime}=2 \mathrm{Cu}(\mathrm{CN})_{3}{ }^{\prime \prime}+\mathrm{CNO}^{\prime}
\end{aligned}
$$

At very high cyanide concentrations higher complexes may also be formed but in $0.005 M \mathrm{KCN}$ there is equilibrium at equal amounts of $\mathrm{K}_{3} \mathrm{Cu}(\mathrm{CN})_{4}$ and $\mathrm{K}_{2} \mathrm{Cu}(\mathrm{CN})_{3}$ (Kunschert ${ }^{3}$ ). As the cyanide concentrations of interest are usually below $0.005 M$ the equations $1-3$ may describe the actual reactions. The experiments described below were carried out in order to test this. In series I copper cyanide precipitates were studied and in series II mixtures of copper(II)ions and cyanide ions in different proportions were examined. III. In connection with the precipitate studies copper(I)cyanide was crystallized in two forms.

\section{PRECIPITATE EXPERIMENTS}

Two gions of cyanide per gatom copper were mixed under nitrogen as $1 M$ solutions and the precipitate washed several times with distilled water, alcohol and ether on a glass filter and finally dried over sulfuric acid. The complex precipitate was suspended in redistilled water at $25^{\circ} \mathrm{C}$ for $8-10$ hours. The clear saturated supernate was then decanted off. The precipitate was again suspended in water. The whole procedure of saturation was repeated until no changes occurred in the supernate (conveniently controlled by the electrical conductivity). 
The mother liquor and washings from the precipitation and the saturated solutions prepared from the precipitate were analysed for cyanide and copper content, and for potential in a copper half-cell. Copper was determined photometrically with diethyl-dithiocarbamate (Braun and Scheffer ${ }^{4}$ ). Cyanide was estimated by means of electrometric titration with silver sulfide as indicator electrode. In the mother liquor also cyanate was determined with the method of Leboucq ${ }^{5}$. The copper potentials were measured under nitrogen at $25^{\circ} \mathrm{C}$ using a brightly polished rod of electrolytic copper as indicator electrode. The rod was polished anew before each measurement. The valve potentiometer was read off to $\pm 1 \mathrm{mV}$.

The results are summarized in Table 1. Obviously the mother liquor contains complex compounds of the type $\mathrm{CuCN}, n \cdot \mathrm{KCN}$ where $n$ is great. For a normal potential $E_{0}=522 \mathrm{mV}$ (Latimer) ${ }^{6}$ the copper(I)ion activity corresponds tó $2.9 \cdot 10^{-7} \mathrm{M}$.

Table 1. Copper potentials and concentrations of copper and cyanide in supernatants from suspensions of copper(I)cyanides.

\begin{tabular}{|c|c|c|c|c|c|}
\hline \multirow{2}{*}{ Test solution } & \multirow{2}{*}{$\begin{array}{l}\text { No. of experi- } \\
\text { ments }\end{array}$} & \multirow{2}{*}{$E_{\mathrm{Cu}} \mathrm{mV}$} & \multirow{2}{*}{$\begin{array}{l}\mathrm{CN} \text { 'mmol } \\
\text { per liter }\end{array}$} & \multirow{2}{*}{$\begin{array}{l}\mathrm{Cu} \text { mmol } \\
\text { per liter }\end{array}$} & gions $\mathrm{CN}^{\prime}$ \\
\hline & & & & & gatom $\mathrm{Cu}$ \\
\hline Mother liquor & 2 & 135 & $565-627 *$ & $\begin{array}{l}17.2- \\
22.6\end{array}$ & $28-33$ \\
\hline $\begin{array}{c}\text { Washings nos. } \\
2-5\end{array}$ & 5 & $\begin{array}{l}-158 \text { to } \\
-176\end{array}$ & $\begin{array}{l}5.95- \\
27.4\end{array}$ & $\begin{array}{l}4.34- \\
10.3\end{array}$ & $1.15-3.36$ \\
\hline $\begin{array}{c}\text { First satura- } \\
\text { tion }\end{array}$ & 8 & $\begin{array}{l}-230 \text { to } \\
-271\end{array}$ & $\begin{array}{l}20.8 \\
35.3\end{array}$ & $\begin{array}{l}15.6 \\
26.2\end{array}$ & $1.19-1.35$ \\
\hline $\begin{array}{l}\text { 4th or later } \\
\text { saturations }\end{array}$ & 7 & $\begin{array}{r}213 \text { to } \\
-83\end{array}$ & $\begin{array}{l}0.149 \\
0.335\end{array}$ & $\begin{array}{l}0.174- \\
0.339\end{array}$ & $0.73-0.99$ \\
\hline
\end{tabular}

In the washings the copper activity has sunk by about 5 powers of 10 and the ratio $\mathrm{CN}: \mathrm{Cu}$ corresponds on an average to the compound $\mathrm{KCu}(\mathrm{CN})_{2}$ (equ. 3) which according to Spitzer ${ }^{7}$ has a solubility of $0.04 \mathrm{~mol}$ per liter at $18^{\circ} \mathrm{C}$.

In the first saturation with the precipitate the copper activity has sunk further a good power of 10 . The ratio $\mathrm{CN}: \mathrm{Cu}$ is less than 2, and evidently the main part of the $\mathrm{KCu}(\mathrm{CN})_{2}$ has been removed, while some cupri-cupro-cyanide $\mathrm{CuCN}, \mathrm{Cu}(\mathrm{CN})_{2}$ still remains.

In the fourth and the following saturations the conductivity is constant at $10^{-5} \mathrm{r}$. o. The more soluble complex copper(1)cyanides seem here to have been

* $\mathrm{CNO}^{\prime}: 1-20 \%$ of the cyanide concentration found. 


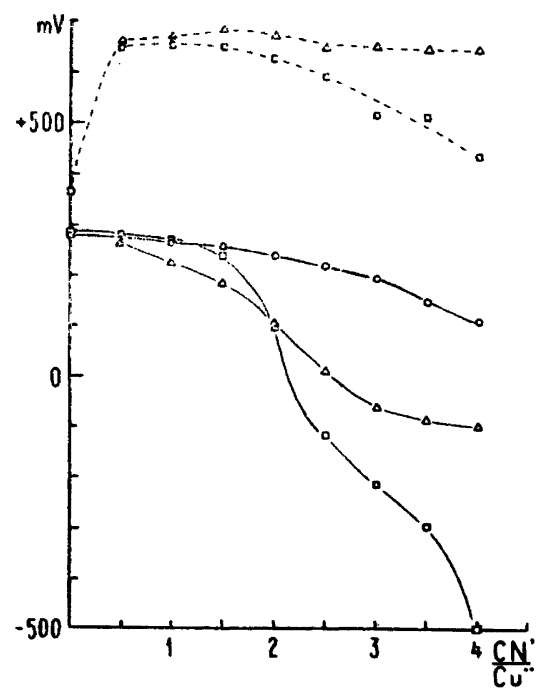

Fig. 1. Copper potentials (full lines) and redox potentials (dotted lines) for mixtures of coppersalts and cyanide.

$\square$ potentials in $0.005 \mathrm{M} \mathrm{CuCl}_{2}$

$\triangle: \begin{array}{r}0.0005: \mathrm{CuSO}_{4} \\ 0.00005\end{array}$

entirely removed, and the remaining precipitate is supposed to be pure $\mathrm{CuCN}$, whose solubility under the prevailing conditions is $0.1-0.3 \mathrm{mmol}$ per liter. The copper potentials are here very labile and thus do not permit any conclusions.

\section{MIXING EXPERIMENTS}

Solutions of $\mathrm{CuCl}_{2}$ or $\mathrm{CuSO}_{4}$ were mixed with solutions of $\mathrm{KCN}$ so that the molar proportions between cyanide and copper were between 0.5 and 4.0 in even steps of 0.5. The concentrations were selected so that the final concentration of each mixture in a series was the same regarding one of the ions. Determinations were made of the potential in the copper half-cell as well as of the oxido-reduction potential. Typical experiments are reproduced in Fig. 1. When the copper concentration is $0.5 \mathrm{mM}$ or higher the copper activity changes rapidly when the $\mathrm{CN}: \mathrm{Cu}$ ratio rises to 1.5 and over indicating complex formation. In weaker solutions, on the other hand, one obtains no such sudden changes of potential, but the reduction of activity takes place evenly within the measured region. This supports the assumption that complex compounds of the type $\mathrm{CuCN}, n \mathrm{KCN}$ are only stable in solutions that in respect of copper are $0.5 \mathrm{~m} M$ or more. In weaker solutions they disintegrate or are not formed.

Also the redox potentials are changed in a similar way to the copper potentials, which confirms the conclusions concerning the complex formation.

As the cyanide-content in the blood from different kinds of animals killed by inhalation of $\mathrm{HCN}$ does not amount to $0.5 \mathrm{mM}$, copper treatment should 
thus give rise only to $\mathrm{CuCN}$ (equ. 1). Hence the full detoxicating copper dose is to be calculated on the basis of 0.5 gatom copper per gion cyanide (cf. Agner ${ }^{8}$ ).

\section{CRYSTALLIZATION OF COPPER(I)CYANIDE}

In the course of the foregoing experiments it was observed that in flasks from the first saturation tests that had been allowed to stand for some time two kinds of crystals arose, dark green and dark red. Systematic experiments showed that besides potassium-containing complex compounds, dark green crystals appeared at room temperature in a suspension of the washed precipitate (see under I). At $40^{\circ} \mathrm{C}$, on the other hand, mostly dark red crystals were formed. These, however, may also arise at room temperature. The red and green crystals thus prepared were indistinguishable from those first observed.

Both kinds of crystals were difficultly soluble, but with $\mathrm{H}_{2} \mathrm{O}_{2}+\mathrm{H}_{2} \mathrm{SO}_{4}$ or $\mathrm{HNO}_{3}$ it was possible to dissolve them completely. For analysis crystals were weighed out and put into a $30 \mathrm{ml}$ distillation flask containing some water. When the air had been driven out by boiling, concentrated $\mathrm{HNO}_{3}$ + some $\mathrm{H}_{2} \mathrm{O}_{2}$ was added, and all cyanide was driven out by continued heating. The cyanide was collected in $0.005 \mathrm{~N} \mathrm{AgNO}_{3}$, whereupon the excess of silver was determined by electrometric titration. The residue in the distilling flask was analysed for copper iodometrically according to Bitskei ${ }^{9}$. Some analytic values are given in Table 2.

Despite the dispersion in the analytic values, one is probably justified in assuming that both the dark green and the dark red crystals have the gross formula $\mathrm{CuCN}$. At least the green crystals are certainly different from the

Table 2. Analyses of copper (I )cyanide crystals.

\begin{tabular}{|c|c|c|c|c|c|c|c|}
\hline \multicolumn{3}{|c|}{ Dark green crystals } & \multicolumn{4}{c|}{ Dark red crystals } \\
\hline $\begin{array}{c}\text { Weight } \\
\mathrm{mg}\end{array}$ & \multicolumn{2}{|c|}{ Micromols } & $\mathrm{Cu}$ & Weight & \multicolumn{2}{|c|}{ Micromols } & $\mathrm{Cu}$ \\
& $\mathrm{CN}$ & $\mathrm{Cu}$ & $\mathrm{CN}$ & $\mathrm{mg}$ & $\mathrm{CN}$ & $\mathrm{Cu}$ & $\mathrm{CN}$ \\
\hline & & & & & & & \\
1.76 & 15.3 & 18.8 & 1.23 & 1.48 & 12.9 & 11.6 & 0.90 \\
1.26 & 12.5 & 11.4 & 0.91 & 1.78 & 11.8 & 13.4 & 1.14 \\
1.23 & 12.8 & 9.6 & 0.75 & 1.64 & 14.5 & 10.7 & 0.74 \\
1.57 & 15.4 & 11.6 & 0.75 & 1.70 & 14.2 & 12.3 & 0.87 \\
1.25 & 9.6 & 10.6 & 1.13 & 1.52 & 11.0 & 10.8 & 0.98 \\
1.49 & 9.8 & 6.5 & 0.66 & 1.38 & 11.8 & 11.8 & 1.00 \\
\hline Mean value & & & 0.91 & & & & 0.94 \\
\hline
\end{tabular}


copper(I)cyanide crystals obtained by Wöhler 10 from lead copper cyanide after precipitation with sulfuretted hydrogen and subsequent evaporation, and crystallographically examined by Dauber ${ }^{11}$.

Preliminary $\mathrm{X}$-ray investigations show that the red modification is monoclinic with the following dimensions of the elementary cell: $a=17.78 \mathrm{kX}$, $b=6.79 \mathrm{kX}, c=21.10 \mathrm{kX}$ and $\beta=99^{\circ}$. The green modification has a rhombic elementary cell with $a=17.80 \mathrm{kX}, b=6.79 \mathrm{kX}$ and $c=21.85 \mathrm{kX} *$.

* We are indebted to Dr. Frans E. Wickman of the Mineralogical Department of the Stockholm University for the X-ray investigations.

\section{SUMMARY}

The reactions between copper(II)ions and cyanide ions have been investigated, in which connection it has emerged that complex copper cyanides are formed or exist only if the copper concentration is $\geqq 0.5 \mathrm{mM}$. In connection herewith, we observed the formation of 2 new copper cyanide crystals that according to the analyses are 2 modifications of copper(I)cyanide.

For the copper treatment of cases of hydrogen cyanide poisoning our results imply that the dose should be calculated on the basis of, at the most 0.5 gatoms of $\mathrm{Cu}$ per gion of cyanide.

\section{BIBLIOGRAPHY}

1. Chistoni, A. Arch. sci. biol. Italy 7 (1925) 1.

2. Kubowitz, F. Biochem. Z. 296 (1938) 443.

3. Kunschert, F. Z. anorg. Chem. 41 (1904) 337.

4. Braun, L., and Scheffer, L. Biochem. Z. 304 (1940) 397.

5. Leboucq, J. J. pharm. chim. 6 (1927) 20.

6. Latimer, W. M. Oxidation states of elements. New York (1938).

7. Spitzer, F. Z. Elektrochem. 11 (1905) 343.

8. Agner, K. Naturwissenschatten 27 (1939) 31.

9. Bitskei, J. Z. analyt. Chem. 102 (1935) 35.

10. Wöhler, Fr. Ann. 78 (1851) 370.

11. Dauber, H. Ann. 74 (1850) 200. 